\title{
Introduction: Radical Teaching About Human Rights Part II
}

by Michael Bennett and Susan O'Malley

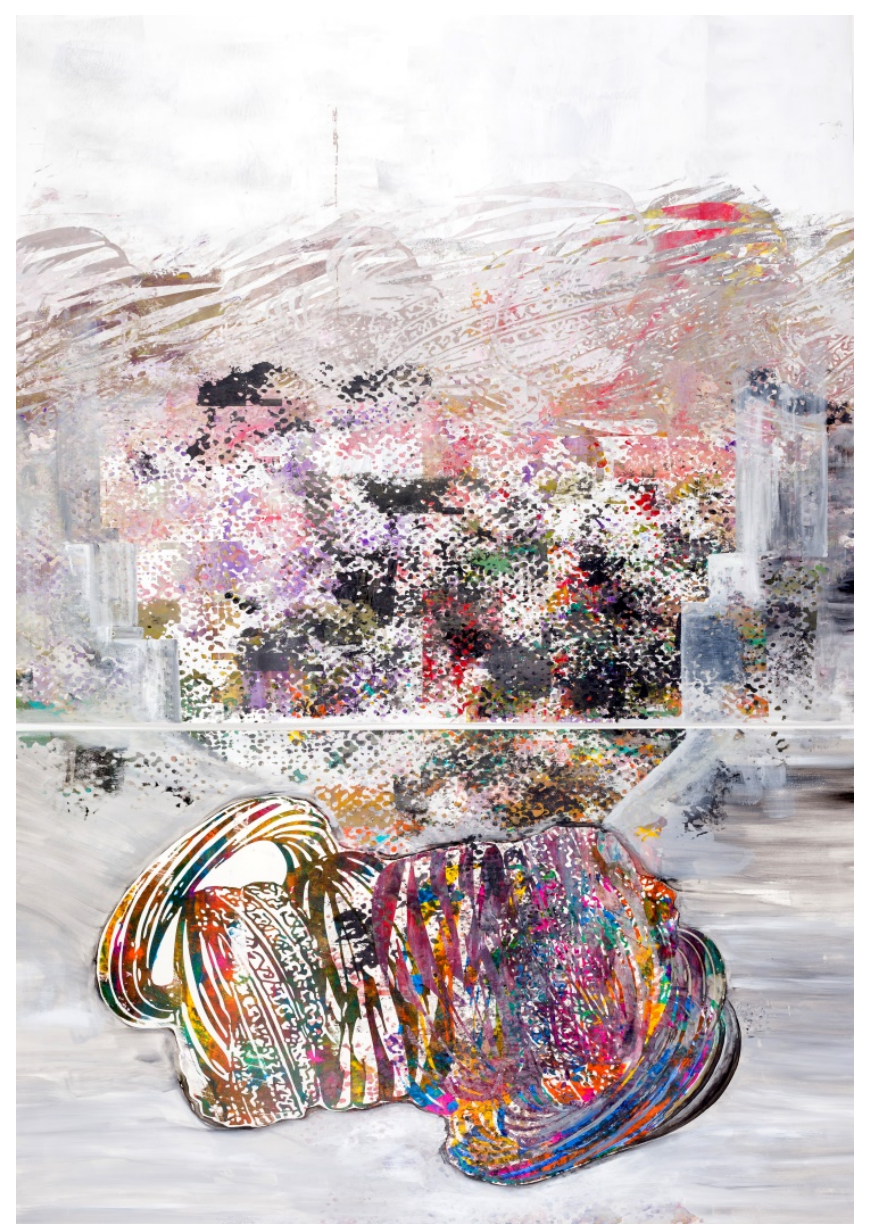

IN THE SERIES ASSOCIATED PRESS, AMANDA HUGHEN MINES THE PRINT EDITION OF THE NEW YORK TIMES TO EXAMINE CONNECTIONS BETWEEN GEOPOLITICS, CLASS, IDENTITY, AND LUXURY GOODS FOR THE PAST YEAR, HUGHEN HAS WORKED PRIMARILY WITH IMAGERY FROM A ' SINGLE EDITION: THE JANUARY 6, 2015 PRINT EDITION OF THE NEW YORK TIMES. THE HEADLINE PHOTO THAT DAY WAS A LARGE COLOR PORTRAIT OF AN AFGHANI MAN WHO, SINCE LOSING BOTH SONS IN THE CONFLICT, SPENDS HIS TIME FERRYING DEAD BODIES BACK TO THEIR FAMILIES ON BOTH SIDES OF THE WAR. ON THE NEXT PAGE, A2, JUST BEHIND HIS PHOTO, WAS AN AD FOR A WEMPE GOLD RING THAT MIMICKED THE FORM OF THE TURBAN OF THE MAN ON THE COVER. 
I n our introduction to the first of these two issues of Radical Teacher devoted to "Radical Teaching About Human Rights," we cautioned that all forms of Human Rights Education (HRE) are not radical. The problem, we pointed out, with rights discourse is that it can mask the politics of how rights are defined, whose rights are recognized, and how they are enforced. This problem becomes evident when HRE is bound up with a neoliberal, or worse than neoliberal, perspective that points fingers at others and rallies troops for supposedly humanitarian interventions while eliding the role of the United States as an imperializing settler colonial state. Fortunately, we have once again received several essays that seem to us to be aware of this danger and provide admirable examples of radical teaching about human rights.

While most educators would turn to the Universal Declaration of Human Rights as the founding document for HRE, we noted that those who shared our radical perspective were more likely to draw on later developments in human rights discourse, such as the International Covenant on Economic, Social and Cultural Rights (ICESCR), the United Nations Declaration on the Rights of Indigenous Peoples, and non-UN-based indigenous or internationalist political movements. We also highlighted the radical potential of the United Nations Declaration on Human Rights Education and Training, which insists that HRE needs to be about, through, and for human rights. This description mirrors our understanding of radical teaching as not a matter of authority figures depositing knowledge in empty vessels (what Paolo Friere called the "banking system" of education), but as a mutual process of awareness and empowerment (what Friere called "conscientization"). The problem with even wellintentioned teachers leading students to predigested epiphanies reminds us of what Eugene Debs said when asked why he advocated for democratic socialism rather than authoritarian political forms: "If I led them into the promised land, someone else could lead them out again."

Our belief that radical teaching is a matter of form as well as content led one in-house reviewer of Rosemary Blanchard's "Mainstreaming Human Rights Education: What's Radical About That?" to answer the question with: Not enough. This reviewer was concerned by Blanchard's assertion that "to the extent that content standards and performance standards govern public education, HRE needs to be there." We were likewise uncomfortable when Blanchard wrote that "It isn't a question of whether or not standards or particular configurations of standards are a good idea" because this has been a big question for us. Past issues of Radical Teacher have strongly opposed the movement for core standards and Learning Outcomes Assessment as reducing the process of education to "teaching to the test," sacrificing form on the altar of content.

However, as co-editors, we appreciated Blanchard's willingness to engage with our concerns and even foreground her disagreement with some of the assumptions made in Radical Teacher's previous issue on HRE and in our call for papers. Blanchard's essay maintains that American illiteracy about human rights and international humanitarian law standards contributes to the climate in which the United States preaches human rights to its perceived opponents while refusing to apply these universal principles to itself. Blanchard's admirable experience with HRE in a variety of formats has led her to believe that from the failure to incorporate into the American educational structure the cultural and linguistic rights of Indigenous peoples and ethnic, linguistic and religious minorities to the refusal to submit to the same standards of international humanitarian law which apply to all combatants, U.S. political and military leaders have been able to rely on the unfamiliarity of most Americans with the fundamental principles of human rights and international humanitarian law to insulate them from effective public scrutiny and meaningful challenge. Blanchard concludes that we need to mainstream human rights education at all levels of public education so it becomes a part of the educational experience of every child and, thus, part of the background of every adult because the risks of having HRE co-opted are dwarfed by the risks of having HRE sidelined.

The problem with even wellintentioned teachers leading students to predigested epiphanies reminds us of what Eugene Debs said when asked why he advocated for democratic socialism rather than authoritarian political forms: "If I led them into the promised land, someone else could lead them out again."

John Hammond's "Teaching Human Rights: Confronting the Contradictions" shares our concern that the risks of HRE being co-opted need to be kept in view while trying to delineate a radical approach to teaching about human rights. This approach means taking on a series of controversies over what human rights are, how they are determined, and how they are (or are not) upheld. Hammond refers to the "possession paradox" that often human rights are declared but many, or even most, people do not actually enjoy them, arguing that in teaching human rights we must convey both the promise of human rights and the discrepancy between that promise and their fulfillment. Hammond reviews a number of controversies in the current application of human rights, many of which arise from that discrepancy. He suggests the use of literary works and simulation games that can sometimes convey meanings more effectively than expository material.

Alexandra Schultheis Moore's "Teaching Mohemadou Ould Slahi's Guantanamo Diary in the Human Rights and Literature Classroom" and Sarah Hamblin's "The Form and Content of Human Rights Film: Teaching Larysa Kondracki's The Whistleblower" each focus on how one text can be taught from a radical perspective on HRE. Moore's essay provides a case study of teaching Slahi's Guantanamo Diary in order to demonstrate how a literary approach can contribute to the study of human rights by both demonstrating the necessity of human rights 
discourses and the ways in which they must be reconsidered in the current geopolitical moment. More specifically, Moore argues that reading the book in its larger legal and political context unveils the ideologies that promote torture in the name of state security. And, it offers a rebuttal to those ideologies through a critical analysis of the distribution of legal personhood and literary subjectivity in the context of Guantánamo. Sarah Hamblin argues that the consistent association of human rights film with historical accuracy as a means of raising awareness has led human rights education to focus on filmic content, with fiction films being used primarily as case studies about particular atrocities or as opportunities to discuss more general ethical issues. While the subject matter of human rights films is certainly a major component of human rights education, Hamblin maintains that this singular focus prohibits students from examining how a film is situated within a specific matrix of geopolitical power relations and cultural presuppositions. This presumption of truth thus normalizes a westernized worldview, obscuring its ideological foundations and the geopolitical structures that give human rights discourse its universality and function. Using Larysa Kondracki's The Whistleblower as a teaching case study, Hamblin demonstrates how an attention to stylistic and generic conventions helps us understand how a film may educate about a particular human rights issue while at the same time propagate the very logics of geopolitical inequality that are implicated in its emergence.

Martha Saxton's "Teaching Human Rights in Jail" and Marissa A. Gutiérrez-Vicario's "More than a Mural: The Intersection of Public Art, Immigrant Youth, and Human Rights" explore radical teaching about human rights in environments that extend beyond the traditional classroom. Saxton discusses the differences between teaching human rights in an elite college and graduate school compared with teaching the same material to incarcerated students inside the prison. The inside students experience the dramatic absence of rights, both in jail and often as well in their previous lives, which almost inevitably were marked by poverty and deprivation. Saxton demonstrates how the different life experiences of the majority of incarcerated students as compared with the majority of college and graduate students position them very differently when they study human rights together inside the prison and think about the implications of particular rights and learn from each other. She concludes that the incarcerated students' discussions tend to be concrete, personal, and sometimes transformative, while the elite college students at first are more theoretical, less personal, and more skeptical. Gutiérrez-Vicario is interested in exploring the construction of global citizenship and engagement around human rights education of immigrant youth through the arts, particularly public art in the form of muralism. She uses the work of Art and Resistance Through Education (ARTE), an organization that engages young people around human rights through the arts, as a case study. Gutiérrez-Vicario discusses the involvement of immigrant youth, predominately from Latin America, in various art projects, as they explore their own sense of identity and belonging in New York City through a project on racial discrimination and immigrant rights.

Finally, Steven Jones's "Stealth Radicalism: Teaching Refugee Rights as Human Rights" describes a human rights course focused on refugee rights through a service-learning project with a refugee resettlement agency. Jones describes his own approach to "radical teaching," his objectives for the course, the course itself, and the impact of the course on the students. One of these impacts, he hopes, is to provide students with a personal point of reference from which to critique U.S. human rights and refugee policies.

Such efforts are necessary and important in this time of a growing refugee crisis. As refugees stream out of Syria and other war-torn parts of the planet, we see various nation states asserting their sovereignty and closing their borders. In the United States, Donald Trump's surge to the front of the pack of Republican presidential aspirants seems to be based largely on his nativist and jingoist (if not racist and fascistic) pledge to seal the borders against migrants and refugees, while rounding up those of Muslim faith who have already made it to these shores (or were here to begin with). Clearly, now more than ever, the assertion and protection of universal human rights (and the need for radical forms of HRE) are crucial for people who are left stateless or made to feel that way.

\section{Works Cited}

\footnotetext{
Freire, Paolo. "Cultural Action and Conscientization." Harvard Education Review 68.4 (1998): 499-521.

United Nations. The Universal Declaration of Human Rights. 1948. Web. 10 Jan. 2016. <www.un.org/en/documents/udhr>.

United Nations. United Nations Declaration on Human Rights Education and Training. 2011. Web. 10 Jan. 2016.

$<$ www.ohchr.org/EN/Issues/Education/Training/Compilation/Pages/Uni tedNationsDeclarationonHumanRightsEducationandTraining(2011).asp
}

(c) $)$ EY-NC-MD

UILIS D-Sorf
This work is licensed under a Creative Commons Attribution-Noncommercial-No Derivative Works 3.0 United States License.

This journal is published by the University Library System of the University of Pittsburgh as part of its D-Scribe Digital Publishing Program, and is cosponsored by the University of Pittsburgh Press.

\section{RADICAL TEACHER}

